\title{
EVALUATION OF THE CONSTRUCTION INDUSTRY'S ECONOMIC SITUATION AND EXPECTED DEVELOPMENT ACCORDING TO MANAGERS OF SMBS
}

\author{
Peter Marinič, Viliam Záthurecký
}

\begin{abstract}
This article is one of the outputs from an international research project focusing on an analysis of small and medium-sized construction companies. It will attempt a more detailed analysis of the expected, though as yet unverified, relationships between selected variables from the current situation of the companies and the anticipated future development emerging from the prior processing of data derived from a questionnaire survey. The relationships between the variables were estimated on the basis of previously processed responses as well as on the basis of theoretically anticipated correlations. Verification of the relationships between the given variables presented in the article was supported by an analysis of the correlations and a comparison of the mean values with a subsequent regression analysis. In accordance with the results of these statistical tests, conclusions were then formed concerning the relationships between the variables.
\end{abstract}

\section{Keywords}

Evaluation of the situation; expected future development; construction industry; small and medium-sized businesses; mean value; regression analysis

\section{Introduction}

As an intelligent human being, a person exists within the environment that surrounds him. This leads to an essential interaction between the environment and the person, which manifests itself in each person's developmental activities or actions. People's actions also take place within a certain time frame which delimits these activities. Therefore, a person has to make decisions on the basis of the information available, which can be described as the influence of his surroundings at a specific time. His decisions are made in the present on the basis of information acquired from the past that has formed his own experiences, or through information which will become evident in the future. That is why it is important to examine and analyze the relevant information from the past which manifests itself in the future through the presentday decisions of a particular individual.

Within the framework of economic theory, the issue of decision making by individuals is examined as part of decision implementation. This activity can be classified as the rational process of selecting one of several options based on the values and preferences of the decision maker. If we assume that we are dealing with an intelligent human being, as was mentioned before, then we can infer that his decisions are made in the form of expectations. [4]

It is possible to differentiate between adaptive and rational expectation. Adaptive expectation is based on the ability of the decision maker to adjust his decisions in the light of past experience, thus adapting while making decisions. If an individual bases his decision making 
not only on past experience but also on probable predictions of future states, then his decision making will be termed rational expectation. Decision making based on rational expectation is free from systematic errors; thus, the decision maker does not consciously realise if his decisions are wrong. [7][10]

It follows on from this that relationships can be assumed between the expected future development of the construction trade and an evaluation of the economic situation of construction companies, which can be related to an evaluation of selected economic indicators, specifically an evaluation of the profit and an evaluation of the development of turnover. These variables, which were subjected to further analysis, were part of a questionnaire devised as part of the empirical investigation. The relationship between the given variables could be viewed as expectation of the future state based on an evaluation of the presence of conditional results achieved in the past. This article takes a closer look at the relationships between the individual variables, and was prompted by previous analyses which had formulated assumptions on the nature of these relationships. [9]

Based on the continuous processing of the results obtained, partial conclusions have already been reached regarding the information contained in the responses to the questionnaire. Responses which have already been partially analysed include the assessment of the company's economic situation, the evaluation of selected variables, i.e. the turnover and profit of the company, and the expectation of future development. These analyses gave rise to the conjecture that there was a relationship between the individual variables under consideration, as well as trends in the evaluation of the individual groups within which this evaluation took place. [20]

The impetus for this article stems from what has been outlined above. It focuses on verifying the existence of relationships between the aforementioned evaluation judgments from the questionnaire respondents, both relationships in the sense of verifying the optimism in one group of assessors in comparison with the results from another group of assessors, as well as the causal relationships between individual variables. The article is aimed at analysing the situation in the Czech construction industry, or more precisely among Czech construction companies, and the results from the Austrian part of the survey are used as a comparative basis for the Czech results.

\section{The construction industry in the Czech Republic}

Businesses connected with the construction industry and the production of building materials are an extremely important part of the national economy as well as the European business environment. They contribute significantly to job creation and provide impetus for competition, innovation, structural adaptation, growth, local supply and the spreading of risk. In the present business sector, which is characterised by increasing dynamism and increasing competitive pressure, but also by the continuing recession, the creation and maintenance of longterm yield from business activities has a special importance for a company's sustained success.

Upon first examination, the development of the data in the construction industry reveals that there was significant growth in the first quarter of 2014. Year-on-year growth in the construction industry in the first quarter of 2014 was $8.4 \%$. There was a marked growth in the volume of building construction, which was $11.0 \%$ year on year. By contrast, civil engineering stagnated and produced a minimal growth of only $0.1 \%$, which can be considered as maintenance work. A significant influence on the increase in the volume of construction output in the Czech Republic was the very warm weather and the mild winter of 2013/2014, and the 
comparatively low basis for the first quarter in 2013, when there had been an exceptionally severe winter with very poor conditions for uninterrupted construction work. Of course, it is necessary to point out that new contracts also contributed to the growth, specifically from public authorities, who in the first quarter of 2014 commissioned $92.8 \%$ more construction orders from construction companies than for the same period in 2013.

A long-term comparison of the development of the construction industry in the Czech Republic continually points to significant decline. Construction output from the start of the year until the end of March 2014 fell in comparison to the previously monitored period by $33.8 \%$ [16].

On the other hand, the number and financial volume of construction orders from public investors increased in the first four months of 2014. In comparison to the same period from the previous year, the planned volume of investments increased by $51 \%$. At the same time there was also an increase of about $63 \%$ in the volume of contracts placed with specific construction companies in terms of invested funds. Traditionally, the largest investor and commissioner of construction contracts in the Czech Republic has been the state. From this perspective, the volume of contracts awarded by public bodies accounts for approximately $30-40 \%$ of the overall operation of the construction industry, and it can only be hoped that this upward trend will continue. According to the Journal of Public Procurements, from January until April 2014, 1,187 construction commissions were announced, which in comparison to the previous year represents a growth of $49.7 \%$ [16]. However, the year-on-year comparison is heavily influenced by changes to the law on public procurements. According to the model adjustments, from the perspective of methodological contrast and objectivity the year-on-year growth in the number of commissions announced was closer to $58.2 \%$.

At present the future development of the Czech construction industry is one of the most serious problems the Czech economy faces (see the conclusions of the CEEC Research, 29.5.2014, Prague). [6] It can only be hoped that the relevant bodies will react to this challenge adequately, i.e. by significantly supporting both projects and practical activities concerning affected operators in the construction industry.

\section{Profile of the research undertaken}

From 2012 to 2013 an international research project, "The development of small and medium-sized businesses in border areas (ROSTAPO)", was carried out at Masaryk University's Faculty of Economics and Administration. It focused on research into small and mediumsized businesses on the border areas of two neighbouring states - the Czech Republic and Austria. Other partners who participated in this project were Fachhochschule Wien der Wirtschaftskammer Wien and the Regional Economic Chamber of South Moravia.

The research into small and medium-sized construction companies as part of the international research project was aimed at evaluating the competitiveness of the construction market and identifying the key factors behind a company's success, as well as the factors which encouraged companies to work together. Another vital part of the questionnaire survey was made up of questions about the managers' assessment of and satisfaction with the state of strategic management in their company, and, in connection to this article, also an evaluation of the economic situation of the companies and the expected future development of the construction industry based on the views of the managers who were questioned.

In terms of methodology, the research was based on a view of the company operating within the relevant market environment. Therefore, the research proceeded from a resource-based 
view, in which resources are the basis of the company's competitive advantage, and hence the success of the company, as well as the determinants for cooperation. However, another approach taken into consideration was a market-based view, which examines the market in which the company in question operates and which influences the success of companies, their competitiveness and their willingness to cooperate. ${ }^{1}$ On the basis of this approach it was then possible to construct a questionnaire survey which was designed to comprehensively map the company and the environment in which the company operates. [12][17]

\section{Profile of the companies participating in the questionnaire survey}

As part of the international project, a questionnaire survey was carried out among small and medium-sized construction companies in the area concerned, i.e. the South Moravian Region, the Federal State of Lower Austria and the city of Vienna. The population was formed on the basis of data available from public databases of registered business entities with restrictions for the appropriate involvement of specific companies in the questionnaire survey. These restrictions included a territorial restriction - to the regions already mentioned - a restriction to small and medium-sized businesses according to European regulations, and a restriction based on company activities falling under Section F according to the NACE classification of economic activities. [8] This formed the population, comprising 1,599 entities from the South Moravian Region, which was then adjusted to 1,310 relevant entities after the exclusion of some firms which had ceased operation or which were no longer involved in the construction industry. On the Austrian side the population was made up of 1,596 companies.

The extent to which the structure and economic situation of the construction companies from the selected sample corresponds with those of construction companies operating throughout the Czech Republic, bearing in mind the above-mentioned restrictions on the selected sample, can be considered, in terms of the applicability of the results obtained from the survey, as a representative result relating to the situation in the whole of the Czech construction industry. [14][15]

The questionnaire survey was carried out in the South Moravian Region in conjunction with the reputable AUGUR consulting agency, s.r.o. from 25 January to 26 March 2013. On the Austrian side, the questionnaire survey was carried out in conjunction with the Market Research Institute MAKAM Research GmbH from 3 April to 28 May 2013. In both cases a combination of methods was used to gather data: an electronic form known as the CAWI method, data gathering by telephone, known as the CATI method, and traditional correspondence methods. This obtained 176 questionnaire responses from the Czech side (11.1\% of the population) and 177 responses from the Austrian side (11.1\% of the population). [19]

1 The approach known as the resource-based view was introduced into economic theory through an article by Wernerfeld and is based on the strategically valuable resources of a company which help to create a competitive advantage for the company through the creation of added value due to their scarcity and uniqueness. The continued exclusivity of the resources depends on these resources being inimitable, non-substitutable and non-transferable. Critics of the approach point to its tautological basis and its definition of a company's resources being too broad and vague.[1][3][5][18]

The approach known as the market-based view comes from Porter's work and is based on the assumption that the competitive advantage of a company is created and maintained by local factors which affect the company and form its competitive advantage. Through further development of the model a sixth force of cooperation was added. [13][11] 


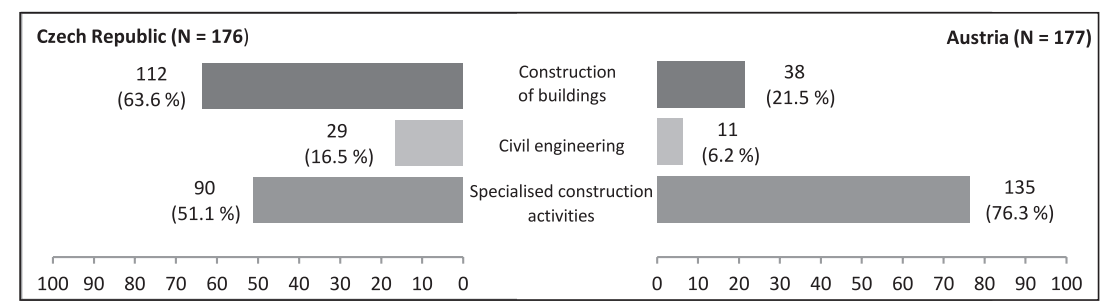

Source: data from the questionnaire survey as part of the ROSTAPO international project (processed by author)

Graph 1: Division of companies according to area of economic activity

The basic sample restricted to section F of the NACE classification of economic activities, i.e. the construction industry section, can be further broken down according to the divisions which make up that particular section. The activities included in the various divisions are the construction of buildings (division 41); civil engineering (division 42) and specialised construction activities (division 43).

Among the Czech companies the main focus was on the area of construction of buildings (112 companies, $63.6 \%$ of respondents), followed by specialised construction activities (90 companies, $51.1 \%$ of respondents). The Austrian side was dominated by companies focused on specialised construction activities (135 companies, $76.3 \%$ of respondents). The different results can be explained using the qualitative information acquired during the personal interviews with representatives of the construction companies within focus groups. The involvement of Czech companies in the construction of buildings can be seen as an indication of their commitment to providing comprehensive services. In this way companies attempt, using the precautionary approach, to incorporate a wide range of construction contracts and not to be limited to specialised construction activities (unlike Austrian companies). A probable reason is Czech companies' concern about being in the position of subcontractor in the event of

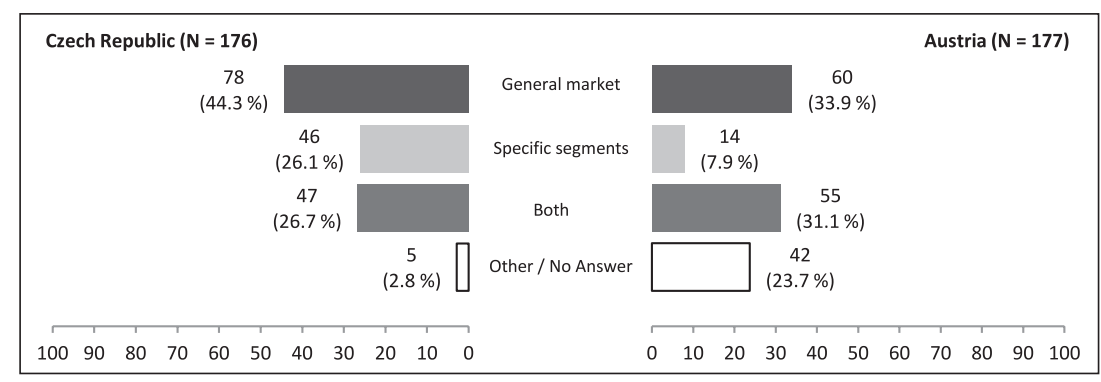

Source: data from the questionnaire survey as part of the ROSTAPO international project (processed by author)

Graph 2: Division of companies according to nature of market four output 


\section{DEVELOPMENT ACCORDING TO MANAGERS OF SMBS}

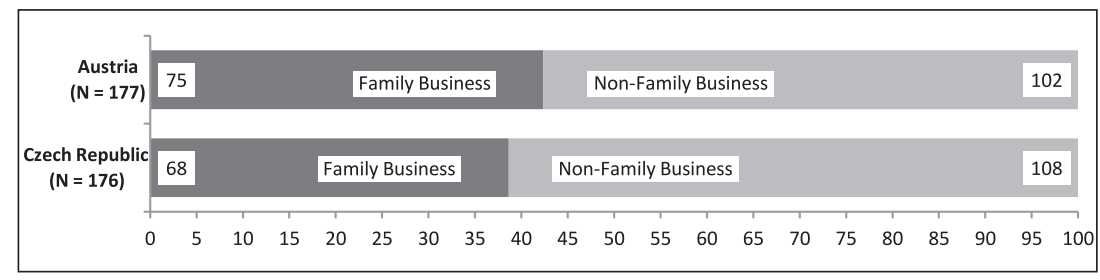

Source: data from the questionnaire survey as part of the ROSTAPO international project (processed by author)

\section{Graph 3: Division of companies into family and non-family businesses}

specialisation, connected with reduced opportunities to influence the final price of construction contracts and pressure to lower the price of subcontracts. Among the Austrian companies there is a significant degree of specialisation in a particular construction activity, which is probably motivated by the increased efficiency of the company and the complex provision of services in connection with the normal practice of using subcontractors even to carry out smaller contracts.

The above graph shows the orientation of companies according to the nature of the market for the construction output of the companies surveyed. With the Czech companies, the general market predominates, which is consistent with the reasoning outlined above concerning the focus of Czech companies based on economic activity. The categorisation of the Austrian companies surveyed is surprising, with only $7.9 \%$ of the companies surveyed operating in a specific segment, particularly in connection with the above-mentioned focus of Austrian companies on specialised construction activities. However, in connection with the aforementioned tendency of Austrian companies to use subcontractors, even for smaller contracts, it can be inferred that the companies are specialised but at the same time operate on the general market.

The construction companies surveyed were also researched in terms of their classification into family and non-family businesses. There are fewer family businesses than non-family businesses among the companies surveyed. They represent $42.3 \%$ of the companies surveyed

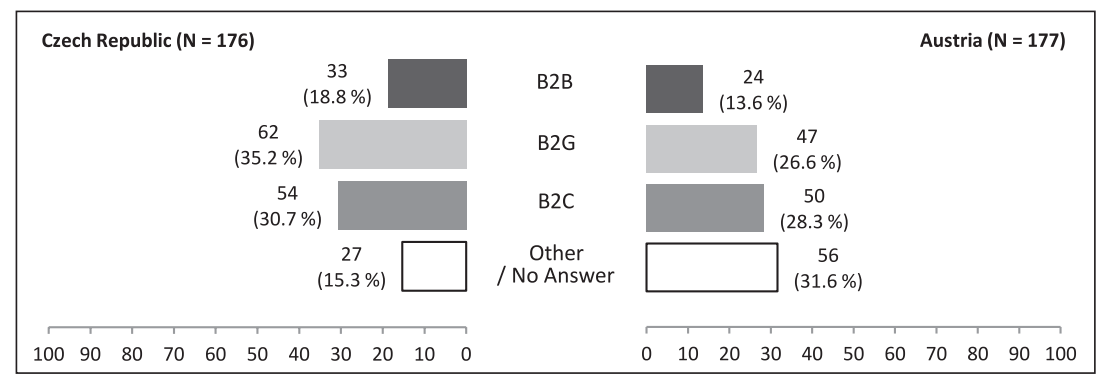

Source: data from the questionnaire survey as part of the ROSTAPO international project (processed by author)

Graph 4: Distribution of companies by predominant customer profile 


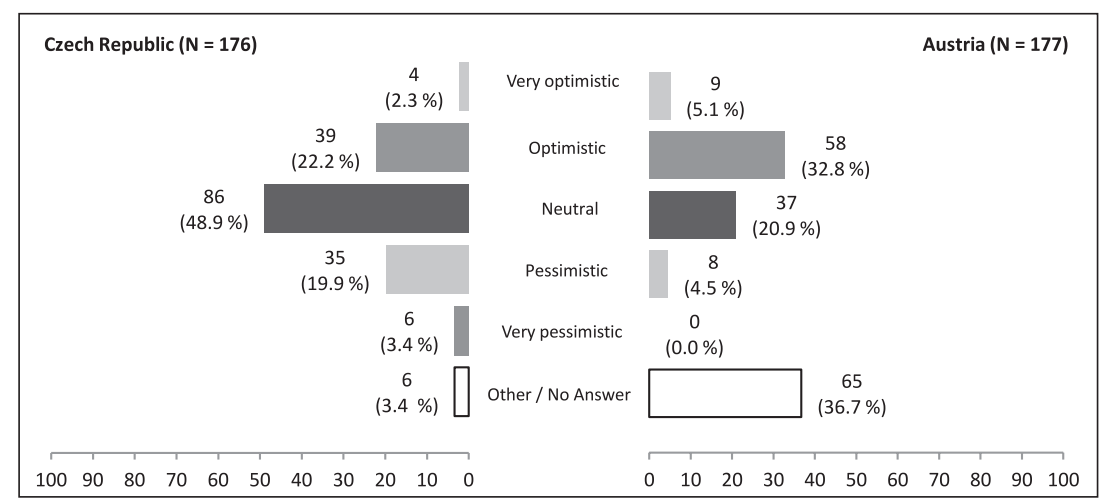

Source: data from the questionnaire survey as part of the ROSTAPO international project (processed by author)

\section{Graph 5: Expected future development of the construction market}

in Austria and 33.8\% in the Czech Republic. This difference could be due to the longer tradition of private enterprise in Austria compared to the Czech Republic.

An interesting perspective on the profile of the construction companies surveyed is offered by an analysis of the predominant customer profile. The data was obtained using open-ended questions in which respondents provided a percentage breakdown of sales achieved in 2012 according to the customer profile. The predominant type of customer was then identified according to the highest percentage of sales, though when the value was the same the predominant type of customer was not determined and was assigned to the group "Other". The public-sector type of customer - B2G - predominated among Czech companies $(35.2 \%$ of surveyed companies), followed by the end-user - B2C (30.7\%). Among the Austrian construction companies the end-user predominated (31.6\%) over the public-sector customer $(28.3 \%)$. In both of the samples, the companies with the lowest prevalence were those with customers in the form of other business entities - B2B (18.8\% of Czech companies, 13.6\% of Austrian companies).

\section{Evaluation of the economic situation and expected future development}

The questionnaire also included an examination of the expected future development of the construction market and an evaluation of the respondents' economic situation over the preceding three years, with an independent evaluation of the growth of turnover and profit.

The expected future development for Czech construction company respondents shows a symmetrical distribution, with the largest grouping being the neutral evaluation (48.9\% of respondents), followed by a positive evaluation $(25.1 \%)$ and then a negative evaluation (23.3\%). Among the Austrian companies an optimistic expectation of future development predominated (37.9\% of respondents), followed by a neutral evaluation (20.9\%), with only a small proportion of negative evaluations (4.5\%). 


\section{DEVELOPMENT ACCORDING TO MANAGERS OF SMBS}

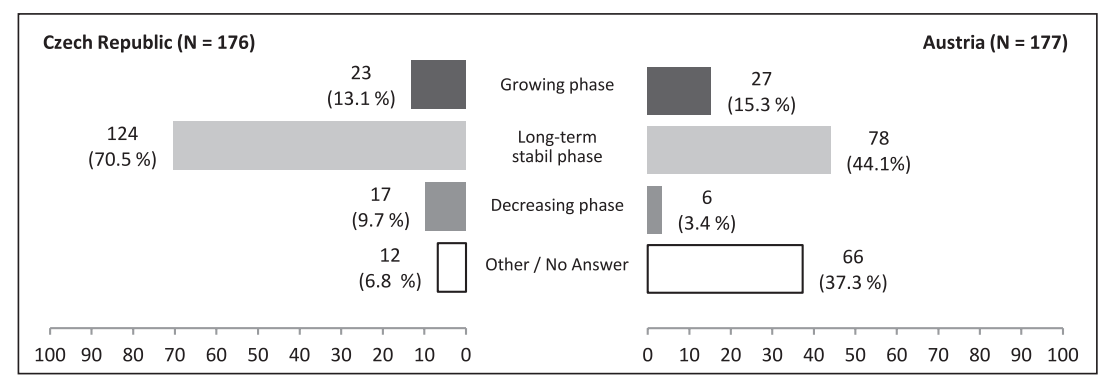

Source: data from the questionnaire survey as part of the ROSTAPO international project (processed by author)

Graph 6: Companies' evaluation of the economic situation

When evaluating the economic situation, the results obtained were largely similar. Among the Czech companies a neutral evaluation predominated, i.e. the evaluation of the company as stable in the long term $(70.5 \%)$, while the proportion of other evaluations, such as the growth phase (13.1\%) and the decline phase (9.7\%), was significantly lower. Among the Austrian companies a neutral evaluation was also predominant (44.1\%), although the difference between the positive (growth phase 15.3\%) and the negative (decline phase 3.4\%) evaluations was more marked than with Czech construction companies.

The evaluation of specific indicators is also mainly represented by neutral expressions from both respondent samples for both the selected indicators. The evaluation from Czech construction companies is represented by a neutral position for $47.2 \%$ of respondents assessing turnover and $46.0 \%$ for a neutral evaluation when considering the development of profit. The result is the same for Austrian companies, i.e. a neutral evaluation predominates $(26.6 \%$ for profit and $30.5 \%$ for turnover).

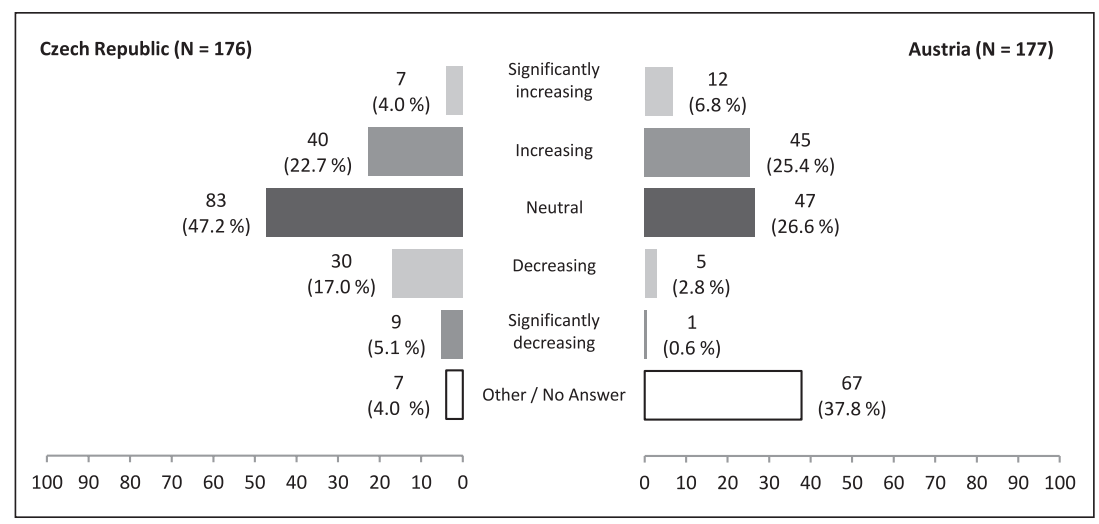

Source: data from the questionnaire survey as part of the ROSTAPO international project (processed by author)

Graph 7: Evaluation of the development of the company's turnover 


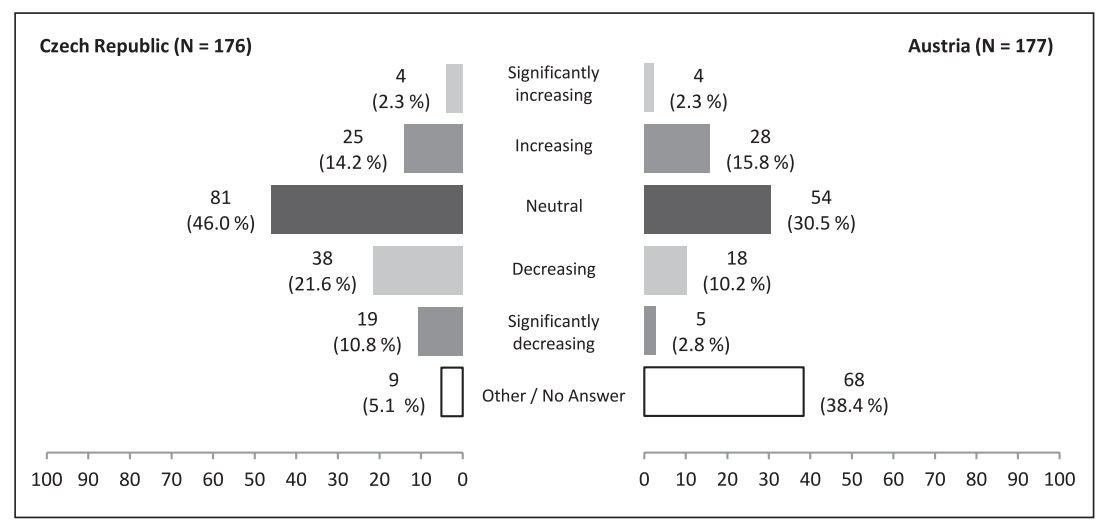

Source: data from the questionnaire survey as part of the ROSTAPO international project (processed by author)

\section{Graph 8: Evaluation of the development of the company's profit}

A difference then becomes apparent in the distribution of the other possible responses. For Czech companies this distribution is more symmetrical for both quantities (positive evaluation for turnover $26.7 \%$, negative evaluation for turnover $22.2 \%$; positive evaluation for profit $16.5 \%$, negative evaluation for profit $32.4 \%$ ). With the Austrian respondents a symmetrical distribution is apparent in the case of the evaluation of profit (18.1\% positive; $13.0 \%$ negative), but when assessing turnover there is more of a positive feeling among Austrian companies (32.3\% positive; $3.4 \%$ negative).

\section{A comparison of evaluation and expectation - Czech Republic vs Austria}

The above diagrams showing the results of the expectation and evaluation of the individual areas related to the company's economic situation can also be evaluated in terms of mutual relationships using descriptive statistics tools. The graph below provides a view of the distribution of individual responses and a comparison of the results between the two sets of data, i.e. between the Czech and Austrian companies. The individual responses are arranged from positive evaluation to negative evaluation in the direction left to right. The top line presents data on the basis of the occurrence of individual responses relative to the total size of the individual groups. The bottom line presents data recalculated after taking into account the relative responses obtained. A similar process can be identified in both groups in the evaluation of the company's economic situation (b) and when assessing the company's profit (d). Different results are apparent in the evaluation of turnover $(c)$ and particularly in the expectation of future development (a). In the last two cases, there was a more positive evaluation from the Austrian companies in comparison with the Czech ones.

Using selected statistical tools, the above statement of a more optimistic evaluation of the situation and expectation of future development by the Austrian companies can be identified in the table below. For each response, lower mean values were obtained from the Austrian companies than from the Czech group. With the values being allocated by an evaluation system based on a rating scale, a lower value means a more positive evaluation. For questions relating to expected future development and questions relating to the evaluation of selected 


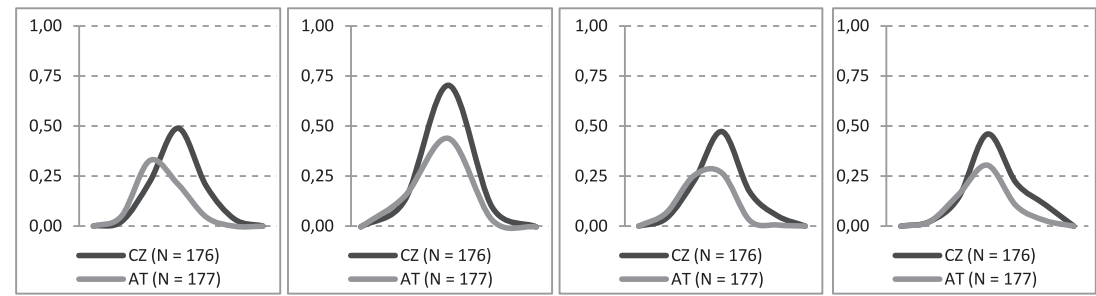

a) Expectation

b) Evaluation

c) Turnover

d) Profit

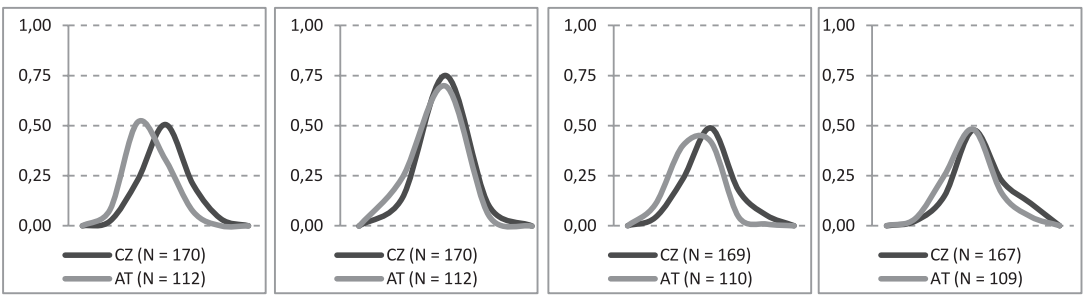

Source: data from the questionnaire survey as part of the ROSTAPO international project (processed by author)

\section{Graph 9: Comparison of results in the Czech Republic vs Austria (total sample / recalculated in relative terms)}

economic variables (turnover and profit), a five-point scale was used, while only a three-point scale was used for company evaluation.

As can be seen from the table, the greatest difference between the mean values of the two groups of companies was obtained for expected future growth (difference in mean value 0.607; $\mathrm{t}(280)=6.316 ; \mathrm{p}=0.000<0.05)$ and for the evaluation of turnover development (difference in mean value $0.528 ; \mathrm{t}(277)=5.063 ; \mathrm{p} 0.000<0.05)$. A smaller difference was obtained with the risk evaluation (difference in mean value $0.331 ; \mathrm{t}(264)=2.963 ; \mathrm{p}=0.003<0.05$ ), and the smallest and statistically least significant difference in mean value was obtained with the evaluation of the economic situation of the company (difference in mean value $0.153 ; \mathrm{t}(273)=2.473 ; \mathrm{p}=0.014<0.05$ ). Therefore, it was also possible to demonstrate the more positive evaluation of the Austrian companies surveyed in comparison with the Czech companies using statistical tools.

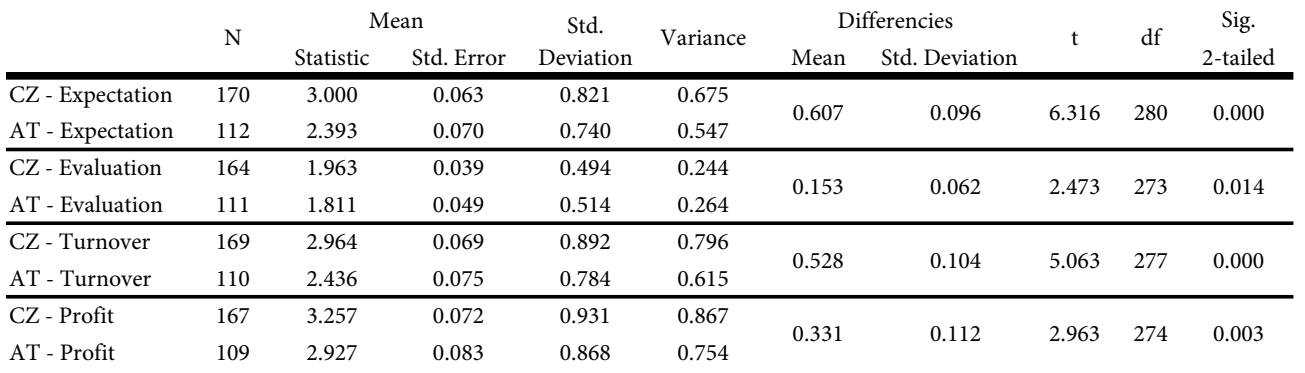

Source: data from the questionnaire survey as part of the ROSTAPO international project (processed by author)

Tab. 1: Selected statistics from individual assessed responses 


\section{Analysis of mutual relationships in selected responses}

The questions about the future expectation of the growth of the construction market, the evaluation of the economic situation of the individual companies as well as the evaluation of the two selected variables, i.e. the companies' turnover and profit, can be intuitively considered as related issues within the questionnaire survey. We will examine this assertion more closely using appropriate statistical tools. We will be particularly interested in whether there is a mutual correlation between the data for the two selected groups and to what extent it is possible to describe their relationship using a regression model.

It is possible to predict connections between the individual variables based on the economic logic of the individual relationships between the variables. If a representative of a selected company evaluates its economic situation and at the same time evaluates the development of profit and turnover, the evaluative judgments relating to the evaluation of profit and turnover will correspond to the evaluation of the company's economic situation. It can thus be assumed that the future expectation of the development of the construction market will also correspond to the evaluation of the economic situation. This is shown in the following example: if the evaluation of the profit and turnover is positive, it can be assumed that there will also be a positive evaluation of the company's economic situation and a positive expectation of the future development of the construction market.

The above assumptions were verified through an analysis of the correlation between each pair of variables, the results of which are presented in the table below. In the corresponding row the table contains the assessed combination of the two selected variables where their mutual relationship is assessed.

On the basis of all the tests carried out, it can be stated that there is a relationship between the individually assessed variables which is represented by the value of the individual coefficient with the appropriate level of significance. In general, the relationship between the assessed variables can be regarded as positive where the coefficient from the selected test achieves positive values. Based on the value of the appropriate coefficient it can be stated that:

$\mathrm{r}>|0.5|$, the relationship can be considered strong

$r>|0.3|$, the relationship can be considered medium

$\mathrm{r}>|0.1|$, the relationship can be considered weak [2]

\begin{tabular}{llccccccc}
\multicolumn{1}{c}{ Variable 1 } & \multicolumn{1}{c}{ Variable 2 } & $\mathrm{N}$ & $\begin{array}{c}\text { Pearson } \\
\text { Correlation }\end{array}$ & $\begin{array}{c}\text { Significance } \\
\text { (2-tailed) }\end{array}$ & $\begin{array}{c}\text { Covariance } \\
\text { Kendall's } \\
\text { tau_b }\end{array}$ & $\begin{array}{c}\text { Significance } \\
\text { (2-tailed) }\end{array}$ & $\begin{array}{c}\text { Spearman's } \\
\text { rho }\end{array}$ \\
\hline CZ - Expectation & CZ - Evaluation & 163 & $0.392^{* *}$ & 0.000 & 0.136 & $0.368^{* *}$ & 0.000 & $0.392^{* *}$ \\
CZ - Evaluation & CZ - Turnover & 162 & $0.542^{* *}$ & 0.000 & 0.190 & $0.512^{* *}$ & 0.000 & $0.542^{* *}$ \\
CZ - Evaluation & CZ - Profit & 160 & $0.506^{* *}$ & 0.000 & 0.175 & $0.472^{* *}$ & 0.000 & $0.499^{* *}$ \\
\hline AT - Expectation & AT - Evaluation & 111 & $0.248^{* *}$ & 0.009 & 0.080 & $0.237^{* *}$ & 0.009 & $0.248^{* *}$ \\
AT - Evaluation & AT - Turnover & 109 & 0.183 & 0.056 & 0.057 & $0.190^{*}$ & 0.039 & $0.197^{*}$ \\
AT - Evaluation & AT - Profit & 108 & $0.315^{* *}$ & 0.001 & 0.114 & $0.301^{* *}$ & 0.001 & $0.318^{* *}$
\end{tabular}

Source: data from the questionnaire survey as part of the ROSTAPO international project (processed by author)

Tab. 2: Analysis of the correlation of individual responses to selected questions 
Whether a given relationship can be considered to be statistically significant depends on the value of significance, which should reach a value which is smaller than the required significance value.

Based on the above assessment of the characteristics of the relationships between variables through the correlation of variables, a positive relationship can be identified in all the calculated pairs. Generally, it is possible to identify a stronger relationship between the assessed variables for the Czech companies surveyed in comparison with the assessed variables for the Austrian companies. The strongest relationship is seen between the indicators of turnover and profit for the evaluation of the economic situation of the company among Czech companies (Pearson coefficient: profit 0.506; turnover 0.542 ). The relationship between the evaluation of the economic situation and the expectation of future development can be termed as medium strong (Pearson coefficient 0.392). The correlation is weaker on the Austrian side. The relationship between the evaluation of the economic situation and turnover can be assessed as medium strong (Pearson coefficient 0.315 ) and the relationship between the evaluation of the company's situation and the future expectation as weak (Pearson coefficient 0.248). In terms of the relationship between the evaluation of the development of turnover and the evaluation of the company's economic situation, this can be described according to the general recommendation as weak (Pearson coefficient 0.183 ), but according to the significance value $(\mathrm{p}=0.057>0.05)$, exceeding the implicitly required level, the existence of this particular relationship is doubtful. However, with another two types of tests the last of the conditions is met, i.e. the relationship can be considered to have been statistically confirmed.

The graph below illustrates the relationship between the individually assessed variables. As has already been mentioned, a three-point scale was used for evaluating the company's economic situation. For the other responses in the questionnaire, a five-point scale was offered, with the positive and negative evaluation being subdivided into two levels. In order to gain a better picture of the relationship between the evaluation of the individual questions and their mutual relationships, for these questions the points were unified on a three-point scale, with a breakdown into positive evaluation, neutral evaluation and negative evaluation or expectation.

The graphs show the relationship between the expected future development of the construction market and the evaluation of the company's economic situation. With the evaluation, the relationship towards the evaluation of the indicators of profit and turnover for the companies is also shown. A similar principle to the rating scale used in schools is applied to the values on the axes, where lower values represent a positive evaluation and higher values represent a negative evaluation. The surface area of each circle in the graph represents the volume of responses from the companies classified accordingly. A straight line at a $45^{\circ}$ angle highlights a directly proportional relationship between the illustrated variables.

A relationship between selected responses to questions from the questionnaire had already been identified using correlation analysis between the individual pairs examined. A positive relationship was identified with varying intensity in the correlation of data. Another way to analyse the relationship between the data was analysis using a regression model. The results of this analysis are shown in the following table.

The table provides an overview of the results from the individual sections of the regression analysis, which are linked to the individual responses to the selected questions and shown in the appropriate columns. From the data presented, it emerges that, as with the correlation analysis, a relationship exists between the dependent (predicted) and independent variables 

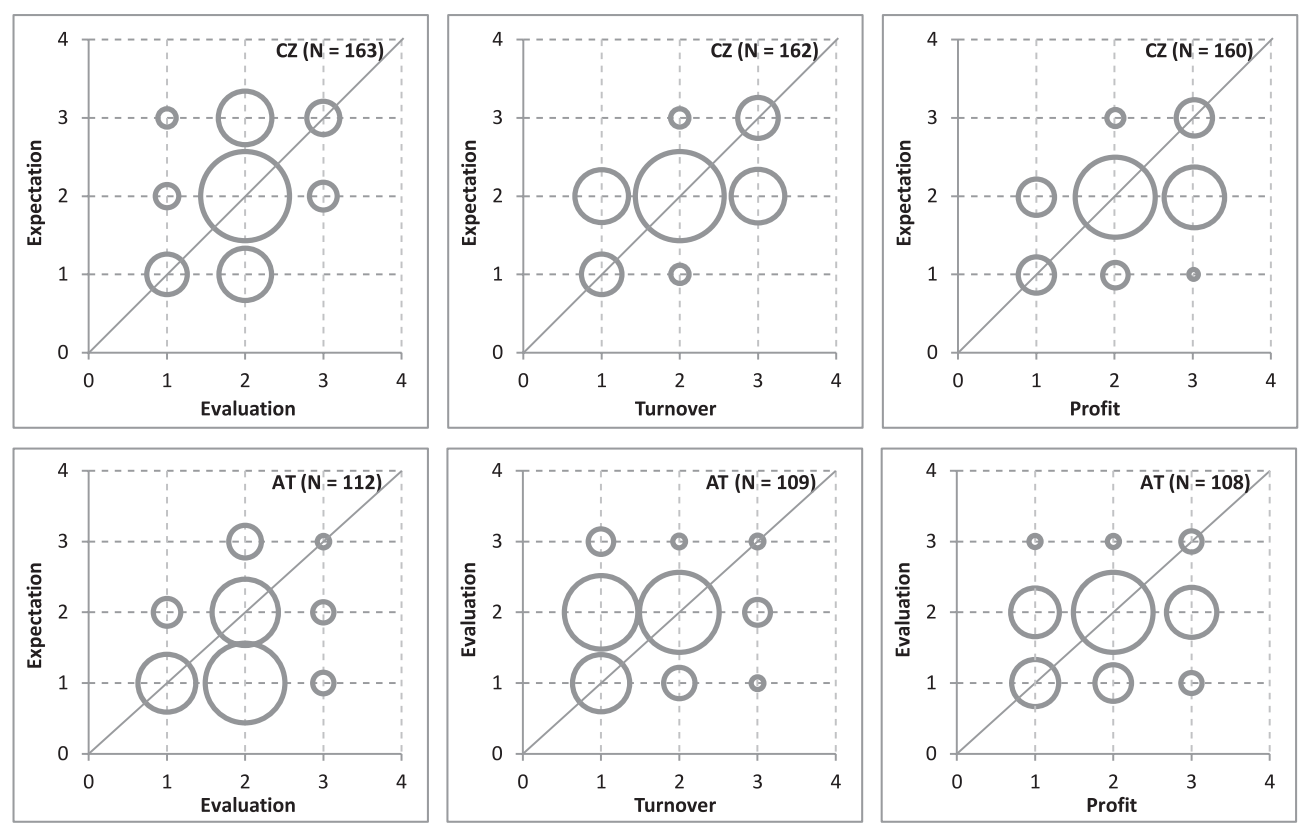

Source: data from the questionnaire survey as part of the ROSTAPO international project (processed by author)

Graph 10: Analysis of mutual relationships between responses to selected questions

- the values shown in the coefficient $\mathrm{R}$ correspond to the values of the Pearson coefficient for the analysis of correlation data. According to the significance values for the individual components of the model, i.e. for constants as well as independent variables, it can be stated that with all of the values observed, statistical significance at the required level of 0.05 was identified. The exception is the model between the evaluation of the company's economic situation and the achieved turnover for Austrian companies, which, as with the correlation analysis, shows statistical significance at a slightly lower level (0.056). Generally, therefore, the individual models can be considered to have been statistically confirmed.

However, if we look at the coefficient of determination $\left(\mathrm{R}^{2}\right)$, which can be interpreted as a measure of the ability of the independent values to describe the course of the dependent variables, then the values determined do not provide entirely satisfactory results. The relationships between the individual variables arranged in order of the coefficient of determination are as follows:

Evaluation of the situation based on the evaluation of turnover - Czech companies $\left(\mathrm{R}^{2}=0.294\right)$

Evaluation of the situation based on the evaluation of profit - Czech companies $\left(R^{2}=0.256\right)$

Expectation based on the evaluation of the situation - Czech companies $\left(R^{2}=0.148\right)$

Evaluation of the situation based on the evaluation of profit - Austrian companies $\left(\mathrm{R}^{2}=0.099\right)$

Expectation based on the evaluation of the situation - Austrian companies $\left(\mathrm{R}^{2}=0.062\right)$

Evaluation of the situation based on the evaluation of turnover - Austrian companies $\left(\mathrm{R}^{2}=0.034\right)$ 


\begin{tabular}{|c|c|c|c|c|c|c|c|}
\hline \multirow{2}{*}{\multicolumn{2}{|c|}{ Dependent Variable }} & \multicolumn{3}{|c|}{ Czech Republic } & \multicolumn{3}{|c|}{ Austria } \\
\hline & & Expectation & Evaluation & Evaluation & Expectation & Evaluation & Evaluation \\
\hline \multicolumn{2}{|c|}{ Independent Variable } & Evaluation & Turnover & Profit & Evaluation & Turnover & Profit \\
\hline \multicolumn{2}{|c|}{$\mathrm{R}$} & $0.392 \mathrm{a}$ & $0.542 \mathrm{a}$ & $0.506 \mathrm{a}$ & $0.248 \mathrm{a}$ & $0.183 \mathrm{a}$ & $0.315 \mathrm{a}$ \\
\hline \multicolumn{2}{|c|}{$\mathrm{R}^{2}$} & 0.154 & 0.294 & 0.256 & 0.062 & 0.034 & 0.099 \\
\hline \multicolumn{2}{|c|}{ Adjusted $\mathrm{R}^{2}$} & 0.148 & 0.289 & 0.251 & 0.053 & 0.025 & 0.091 \\
\hline \multicolumn{2}{|c|}{ Std. Error of estimation } & 0.644 & 0.419 & 0.428 & 0.613 & 0.511 & 0.484 \\
\hline \multicolumn{2}{|c|}{ Durbin-Watson } & 2.031 & 2.132 & 2.219 & 2.196 & 2.068 & 2.073 \\
\hline \multirow[t]{4}{*}{ Constant } & $\mathrm{B}$ & 0.910 & 1.222 & 1.195 & 0.917 & 1.522 & 1.366 \\
\hline & std. Error & 0.207 & 0.097 & 0.110 & 0.214 & 0.134 & 0.134 \\
\hline & $\mathrm{t}$ & 4.399 & 12.653 & 10.850 & 4.284 & 11.643 & 10.184 \\
\hline & Sig. & 0.000 & 0.000 & 0.000 & 0.000 & 0.000 & 0.000 \\
\hline \multirow{4}{*}{$\begin{array}{c}\text { Independent } \\
\text { Variable }\end{array}$} & B & 0.552 & 0.381 & 0.358 & 0.304 & 0.158 & 0.224 \\
\hline & std. Error & 0.102 & 0.047 & 0.048 & 0.114 & 0.082 & 0.066 \\
\hline & $\mathrm{t}$ & 5.403 & 8.157 & 7.374 & 2.676 & 1.930 & 3.416 \\
\hline & Sig. & 0.000 & 0.000 & 0.000 & 0.009 & 0.056 & 0.001 \\
\hline
\end{tabular}

Source: data from the questionnaire survey as part of the ROSTAPO international project (processed by author)

\section{Tab. 3: Regression model}

Therefore, the best model is the model of Czech construction companies' evaluation of the economic situation according to their evaluation of the turnover achieved, as in this model the evaluation of turnover is described by $29.4 \%$ of the evaluation of the economic situation of the relevant company. The worst result is for the model of the Austrian companies, where the level of ability to describe the course of the evaluation of the situation using an evaluation of the turnover is only $3.4 \%$.

\section{Discussion of the results}

From the results presented above, it can be stated that there is greater optimism among Austrian construction companies than among Czech ones. This assertion follows on from the difference that was demonstrated between the calculated mean values for the individual variables, where in all cases lower mean values were identified for Austrian companies in comparison with Czech ones.

Relationships between intuitively predicted variables were also identified and statistically verified, i.e. relationships between expected future growth and the evaluation of the company's economic situation, and also relationships between the evaluation of the company's situation and the evaluation of the development of the indicators of turnover and profit. From the results it emerges that these relationships are statistically more important for Czech construction companies than for Austrian companies. This assertion is based on the results of the Pearson coefficient in the correlation analysis and the relevant coefficient of significance.

Similar results were also identified using linear regression analysis, on the basis of which it is possible to construct models describing the relationship between the variables in the form of equation interdependence. However, the resulting values characterising the significance of the relationships and characterising the possibility of deriving the course of independent variables according to the development of independent variables show relatively low values. 
These values ranged between $3.4 \%$ and $29.4 \%$. These low values explain the behaviour of the dependent variables only to a small extent and they leave scope for the identification of other factors concerning the expectation of future development. However, in the evaluation of the company's economic situation they indicate that companies produce their evaluation based on factors other than turnover and profit. This is particularly the case for Austrian companies, whose results show a lower capability of the models in comparison with Czech companies.

\section{Conclusions}

This article is a response and supplement to the project "The development of small and medium-sized businesses in border areas" which focuses on construction companies. It is based on previous findings which pointed to differences in the expected future development of construction companies and the evaluation of their economic situation, and which were verified using statistical tools. Previously, the project had indicated two possible ways to explain the positive mood in certain groups of businesses within both sets. The motivation for this article was therefore to identify and, through the use of statistical tools, verify the predicted mutual relationship between selected variables.

On the basis of the results from this analysis, the hypothesis about the more positive attitude of the Austrian construction companies in comparison with the Czech construction companies was confirmed. The positive relationship between the evaluation of selected indicators (turnover and profit) in relation to the evaluation of a company's economic situation was also confirmed, as was the relationship of this evaluation of the situation in relation to expected future growth. It can, therefore, be concluded that a more optimistic evaluation of the growth of the indicators (turnover and profit) is consistent with the evaluation of the company's situation and with future expectation. Therefore, the more successful businessmen are the more optimistic ones, and the less successful are more pessimistic. This statement, however, must be treated with the necessary degree of caution as only a relatively weak explanatory power of the individual dependent variables could be identified from the determining factors. This was particularly true for the Austrian companies. It can, therefore, be stated that the individual evaluations, together with expectation, are also formed by other factors.

Those interested in further information from the wider context of the research are recommended to contact the authors of this article, who are able to provide these results in the form of specialist monographs. Information relating to the legal analysis of the environment in which this project was conducted is also available.

\section{References}

[1] Barney, J.B., Firm Resources and Sustained Competitive Advantage. Journal of Management; 17, (1), pp. 99-120. 1991

[2] Field, A., P. Discovering statistics using SPSS: (and sex, drugs and rock ' $n$ ' roll). 3rd ed. Los Angeles: Sage, 2009, xxxiii, 821 pp. ISBN 9781847879066

[3] Grant, R.M., The Resource-Based Theory of Competitive Advantage: Implications for Strategy Formulation. California Management Review; 33, (3), pp. 114-135. 1991

[4] Kahneman, D.; Tversky, A. Choice, Values, Frames. Cambridge University Press. 2000. ISBN 0-521-62172-0 
[5] Kraaijenbrink, J; Spender, J. C.; GROEN, A. The resource-based view: A review and evaluation of its critiques. 200a 9

[6] Kvartální analýza českého stavebnictví 2Q/2014. CEEC Research [online] [cit. 2014-06-10] available at: http://www.ceec.eu/research/

[7] Lucas, R. E. Jr.; Sargent, T. Rational Expectation. Minneapolis: University of Minnesota Press, 1981.

[8] Marinič, P. Rozvoj stavebných podnikov - Kritéria obmedzení základného súboru podnikov. In Štefan Majtán. Aktuálne problémy podnikovej sféry. Bratislava: Vydavatelstvo EKONÓM, 2012. pp. 298-303, 6 pp. ISBN 978-80-225-3427-7

[9] Marinič, P.; Záthurecký, V. Stavebnictví pohledem českých a rakouských managerů stavebních podniků. In MAGNANIMITAS. MMK 2013 - Mezinárodní Masarykova konference pro doktorandy a mladé vědecké pracovníky 2013 (ID: 2013025). Hradec Králové: MAGNANIMITAS, Hradec Králové, Czech Republic, 2013. pp. 1045-1053, 9 pp. ISBN 978-8087952-00-9

[10] Muth, J. F. Rational Expectations and the Theory of Price Movements. Econometrica, 1961, No. 29

[11] Nalebuff, B., J.; Brandenburger, A., M. Co-operation. London: HarperCollins, 1996. xiv, 290 pp.

[12] Odehnalová, P. Porterova analýza 5 sil v odvětví stavebnictví. In Ekonomická univerzita v Bratislavě. Aktuálne problémy podnikovej sféry. 1st ed. Bratislava: Ekonóm, 2012. pp. 386-392, 7 pp. ISBN 978-80-225-3427-7

[13] Porter, M., E. Konkurenční strategie: metody pro analýzu odvětví a konkurentů. 1st. ed. Prague: Victoria Publishing, 1994, 403 pp. ISBN 8085605112

[14] Richter, J. Ekonomická analýza malých a středních stavebních podniků. In Štefan Majtán. Aktuálné problémy podnikovej sféry. Bratislava: EKONÓM, 2012. pp. 425-429, 5 pp. ISBN 978-80-225-3427-7.

[15] Richter, J. Komparace vybraných kvantitativních ukazateli̊ v odvětví stavebnictví. 1st ed. Brno: Masaryk University, 2013. pp. 120-126, 7 pp. ISBN 978-80-210-6187-3

[16] Statistika stavebnictví. Český statistický úřad. [online] [cit. 2014-06-12] available at: http://www. czso.cz/csu/redakce.nsf/i/stavebnictvi

[17] Švandová, E. Koncepční východiska empirického šetření "Rozvoj podnikư”. In Štefan Majtán. Aktuálne problémy podnikovej sféry. Bratislava: Vydavatelstvo EKONÓM, 2012. pp. 574-579, 6 pp. ISBN 978-80-225-3427-7

[18] Wernerfield, B. The Resource-Based View of the Firm. Strategic Management Journal; 5, (2), pp. 171-180. 1984

[19] Záthurecký, V.; Kessler, A.; Schweiger, CH.; Odehnalová, P.; Richter, J.; Schmid, J.; Schöllauf, V.; Kostík, P.; Švandová, E.; Marinič, P. Rozvoj malých a středních podniků v př́hraničních oblastech: Výsledky uskutečněného výzkumu. 1st ed. Brno: Masaryk University, 2013. 190pp. n.a. ISBN 978-80-210-6656-4.

[20] Záthurecký, V.; Marinič, P. Analýza očekávání vývoje stavebnictví pohledem manažerů stavebních podniku․ Ekonomika a management, Prague: University of Economics in Prague, 2013, year 2013, first edition, pages unnumbered. ISSN 1802-8934

Peter Marinič \& Viliam Záthurecký Masaryk University

Faculty of Economics and Administration

Department of Corporate Economy

marinic@mail.muni.cz

zathurecky@econ.muni.cz 